\title{
POTENSI CEMARAN BAKTERI Escherichia coli PADA LIMBAH CAIR RUMAH POTONG AYAM (RPA) TERHADAP LINGKUNGAN DI KOTA MAGELANG
}

\author{
Alfian Syarifuddin ${ }^{1 *}$, Fitriana Yuliastuti ${ }^{2}$, Missya Putri Kurnia Pradani ${ }^{3}$ \\ 1,2,3 Departemen Farmasi, Fakultas Ilmu Kesehatan, Universitas Muhammadiyah \\ Magelang, Jalan Mayjen Bambang Soegeng, Glagak, Sumberrejo, Kec. \\ Mertoyudan, Magelang 56172, Jawa Tengah, Indonesia \\ *Email: ${ }^{1}$ alfiansy@ummgl.ac.id; ${ }^{2}$ fitrianayuliastuti@ummgl.ac.id; \\ 3 missyaputri@gmail.com
}

Tanggal Submisi: 29 April 2020; Tanggal Penerimaan: 27 Mei 2020

\begin{abstract}
ABSTRAK
Kualitas air secara biologis ditentukan oleh banyak parameter, antara lain parameter mikroba pencemar/ patogen. Bakteri Escherichia coli merupakan salah satu bakteri yang menjadi salah satu parameter kualitas suatu air. Jumlah kasus diare di Kota Magelang tahun 2014 mengalami kenaikan dibanding kasus diare tahun 2013, yaitu sebanyak 3.577 kasus dengan persentase sebesar 139,59\% yang disebabkan oleh bakteri. Penelitian ini dilakukan untuk mengetahui ada tidaknya cemaran bakteri Escherichia coli dan mengetahui nilai Angka Lempeng Total (ALT) cemaran bakteri Escherichia coli pada air bilasan pada Rumah Potong Ayam (RPA) yang dapat berpotensi sebagai pencemar di lingkungan Kota Magelang. Metode yang digunakan dalam penelitian ini adalah cawar sebar dengan menggunakan media untuk pengujian adalah media TBX agar. Hasil penelitian menunjukkan adanya cemaran bakteri Escherichia coli yang melebihi $1 \times 10^{1} \mathrm{CFU} / \mathrm{ml}$ pada air bilasan ayam pada beberapa RPA di Kota Magelang, yaitu $61,1 \%$ sampel uji atau sekitar 11 tempat sampling dari total sebanyak 18 tempat pemotongan ayam. Hasil tersebut menunjukkan bahwa air hasil bilasan tersebut dapat berpotensi sebagai salah satu sumber cemaran bakteri Escherichia coli pada daging ayam dan air tanah lingkungan sekitar pembuangan limbah air bilasan. Hanya terdapat 38,9\% dari 18 RPA masih memenuhi ambang batas cemaran bakteri Escherichia coli. Oleh karena itu, perlu adanya langkah-langkah strategis berikutnya, yaitu pengolahan air limbah RPA dengan proses biofilter, serta dapat disosialisasikan terkait cara mengolah daging yang benar.
\end{abstract}

Kata Kunci: Air, Angka lempeng total, Escherichia coli, Rumah potong ayam.

ISSN 1979-7621 (Print). ISSN 2620-7761 (Online)

\begin{abstract}
Biological water quality is determined by many parameters, including pollutant / pathogen microbial parameters. Escherichia coli bacteria is one of the bacteria that becomes one of the parameters of the quality of water. The number of cases of diarrhea in Magelang City in 2014 increased compared to 2013 cases of
\end{abstract}


diarrhea, which was 3,577 cases with a percentage of $139.59 \%$ caused by bacteria. This study was conducted to determine the Escherichia coli contamination and to know the value of the Total Plate Count Escherichia coli bacterial contamination in rinse water in Chicken Slaughterhouses which could potentially act as pollutants in the City of Magelang. The method used in this research is scattered cawar by using media for testing was TBX agar. The results showed that Escherichia coli from chicken's rinse water indicated more than $1 \times 10^{1} \mathrm{CFU} / \mathrm{ml}$ in several Chicken Slaughterhouses in Magelang City, which was found in 11 of 18 sampling points or as much as $61.1 \%$. These results indicate that the rinse water can potentially be one of the sources of Escherichia coli in the chicken meat and the environment. There was $38.9 \%$ of chicken slaughters which was below the Escherichia coli contamination threshold. Therefore, it is necessary to have the next strategic steps, namely the treatment of wastewater by biofilter process and can be socialized about how to process meat properly.

Keywords: Chicken slaughterhouse, Escherichia coli, Total plate count, Water.

\section{PENDAHULUAN}

Air merupakan salah satu komponen lingkungan yang memiliki fungsi penting bagi kehidupan manusia. Air secara tidak langsung juga menunjang pembangunan perekonomian. Ditinjau dari kebutuhan, air yang digunakan untuk memenuhi kehidupan penduduk, maka perlu diperhatikan kualitas air tersebut(Imamudin 2001).

Kualitas air secara biologis ditentukan oleh banyak parameter, antara lain parameter mikroba pencemar atau patogen. Banyak mikroba yang sering mencemari air, khususnya pada air tanah dangkal. Mikroba yang paling berbahaya adalah mikroba yang berasal dari feses, yaitu bakteri Escherichia Coli. Mikroba yang berasal dari air yang tercemar dapat menyebabkan gangguan kesehatan bagi manusia(Pakpahan, Picauly, and Mahayasa 2015).

Beberapa bakteri yang merupakan indikator kualitas suatu perairan adalah coliform, Escherichia coli, dan Salmonella(Arifudin,
Khotimah, and Mulyadi 2013). Escherichia coli adalah bakteri penyebab diare terbanyak setelah rotavirus(Halim et al. 2017). Jumlah kasus diare di Kota Magelang tahun 2014 mengalami kenaikan dibanding kasus Diare tahun 2013, yaitu 3.577 kasus dengan persentase sebesar 139,59\%. (Anon n.d.)

Berdasarkan latar belakang tersebut, tujuan dari penelitian ini adalah untuk mengetahui ada tidaknya cemaran bakteri Escherichia coli dan mengetahui nilai Angka Lempeng Total (ALT) cemaran bakteri Escherichia coli pada air hasil bilasan pemotongan ayam di Kota Magelang.

\section{METODE PENELITIAN}

Penelitian ini menggunakan
desain penelitian eksperimental.
Pengambilan sampel pada penelitian ini
adalah sampel air tanah di 18 lokasi
usaha Rumah Potong Ayam (RPA) di
wilayah kota Magelang. Seluruh
pengujian penelitan ini dilakukan di
Laboratorium mikrobiologi,
Departemen Farmasi, Fakultas Ilmu


Kesehatan, Universitas Muhammadiyah Magelang.

Alat: hot plate, shaker, mikropipet, Laminer Air Flow, Inkubator, Oven, Autoclave, cawan petri, gelas beker, dan colony counter.

Bahan: media selektif Tryptone Bile Xglucuronide atau TBX (HIMEDIA), Aquades steril.

Prosedur dalam penelitian ini meliputi pembuatan media pengujian, proses sterilisasi alat dan bahan yang akan di pergunakan, pengambilan sampel uji, pengujian, pengamatan dan perhitungan jumlah angka lempeng total bakteri E-Coli, analisis data.

\section{Pembuatan Media TBX}

Pembuatan media selektif pengujian dilakukan dengan menimbang $36,5 \mathrm{~g}$ media kemudian dilarutkan dalam 1 Liter aquades steril. Panaskan sampai medidih untuk melarutkan keseluruhan media (Sasongko 2014).

\section{Sterilisasi Alat dan Bahan}

Media yang telah dilarutkan disterilkan pada suhu $121^{\circ} \mathrm{C}$ selama 15 menit pada autoklaf (Syarifuddin, Sulistyani, and Kintoko 2019). Seluruh peralatan gelas dan botol sampel yang akan digunakan dilakukan sterilisasi dengan menggunakan oven pada suhu $180^{\circ} \mathrm{C}$ selama 1 jam(Syarifuddin, Sulistyani, and Kintoko 2018).

\section{Preparasi Sampel}

Preparasi sampel dengan cara mengambil $5 \mathrm{~mL}$ air disetiap air hasil bilasan karkas yang akan dilakukan pengujian. Air hasil pengambilan dimasukkan ke dalam wadah secara aseptik. Masing- masing sampel air diambil $1 \mathrm{~mL}$ dan dimasukkan ke dalam tabung yang berisi $9 \mathrm{~mL}$ aquades steril $\left(10^{-1}\right) \quad$ kemudian dilakukan pengenceran bertingkat $10^{-2}, 10^{-3}, 10^{-4}$, dan $10^{-5}$. Masing-masing pengenceran dilakukan penanaman Pada media spesifik, yaitu media TBX dengan teknik spread plate. Tuang sebanyak $100 \mu \mathrm{L}$ cairan sampel pada masingmasing media dan diratakan menggunakan spreader steril. Perlakuan per pengenceran dilakukan inkubasi selama 18-24 jam pada suhu $37^{\circ} \mathrm{C}$ (Syarifuddin, Kamal, et al. 2019).

\section{Analisis Data}

Jumlah koloni bakteri yang muncul dihitung dengan menggunakan alat colony counter (Sutiknowati 2018). Masukkan ke dalam rumus untuk penentuan Angka Lempeng Total (ALT) (Ahmad 2018a).

$\mathrm{ALT}=$ (Jumlah Koloni/ volume sampel) x pengenceran

\section{HASIL DAN PEMBAHASAN}

Penentuan lokasi pengambilan sampel berdasarkan observasi lahan pada tahun 2019, terdapat 18 Tempat Pemotongan Ayam dengan kegiatan operasional aktif di Kota Magelang. Jadwal operasional produksi masingmasing TPA khususnya pemotongan ayam, yaitu rentang pukul 21.30 06.00 WIB. Berikut daftar TPA yang yang disajikan pada Tabel 1 . 
Tabel 1. Data Rumah Potong Ayam (RPA) di Kota Magelang

\begin{tabular}{rlcll}
\hline No. & \multicolumn{1}{c}{ Lokasi } & $\begin{array}{c}\text { Produksi/ } \\
\text { hari (ekor) }\end{array}$ & Keterangan & Jam Kerja \\
\hline 1. & Tidar krajan A & 100 & aktif & 02.00 \\
2. & Tidar krajan B & 50 & aktif & 04.30 \\
3. & Tidar krajan C & 60 & aktif & 04.30 \\
4. & Tidar krajan D & 300 & aktif & 01.00 \\
5. & Tidar krajan E & 50 & aktif & 23.00 \\
6. & Tidar krajan F & 200 & aktif & 01.00 \\
7. & Tidar dudan A & 75 & aktif & 02.00 \\
8. & Tidar dudan B & 40 & aktif & 24.00 \\
9. & Tidar dudan C & 30 & aktif & 23.30 \\
10. & Kp. Tulung & 33 & aktif & 04.00 \\
11. & Menowo & 50 & aktif & 04.00 \\
12. & Salakan & 20 & aktif & 24.00 \\
13. & Tidar Warung A & 70 & aktif & 04.30 \\
14. & Tidar Warung B & 50 & aktif & 24.00 \\
15. & Potrobangsan & 10 & aktif & 06.00 \\
16. & Nambangan A & 20 & aktif & 03.00 \\
17. & Nambangan B & 15 & Aktif & 05.00 \\
18. & Paten Jurang & 20 & Aktif & 02.00 \\
\hline
\end{tabular}

\section{Pengamatan Koloni}

Pengujian pada masing-masing

Tempat Pemotongan Ayam

dilakukan sampling. Setiap sampling

dilakukan pengujian dengan media

spesifik TBX untuk mengetahui cemaran bakteri Escherichia coli. Agen kromogenik X-Glucuronide dalam media ini membantu mendeteksi aktivitas glukururididase. Sel-sel Escherichia coli menyerap xglukuronide dan glukuronidase intraseluler memisahkan ikatan antara kromofor dan glukuronid. Kromofor yang dilepaskan memberi warna hijau kebiruan pada koloni(Barcella, Barbaro, and Rogolino 2016).

Hasil pengamatan pengujian sampel diperoleh ditunjukkan pada
Tabel 2, hasil bahwa 3 dari 18 sampel uji tidak menunjukkan adaya pertumbuhan koloni spesifik bakteri Escherichia coli, yaitu sampel Menowo, Tidar warung A, dan Paten jurang. Namun, selain 3 sampel yang tidak terdapat pertumbuhan koloni Escherichia coli, terdapat 4 tempat yang lain angka cemaran yang masih dapat masuk dalam kriteria, yaitu Tidar Dudan C, Salakan, Potrobangan, dan Nambangan A. Sedangkan 12 sampel uji lainya menunjukkan adanya pertumbuhan koloni berwarna hijau kebiruan pada media TBX dengan jumlah lebih dari batas kriteria yang ditetapkan. Berikut perbedaan visual hasil pengujian sampel pada media TBX. 


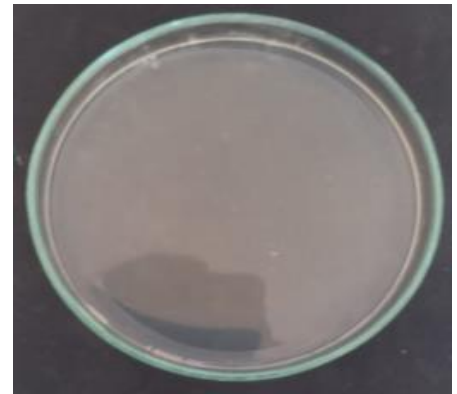

Gambar 1. Media TBX tanpa Pertumbuhan Bakteri.

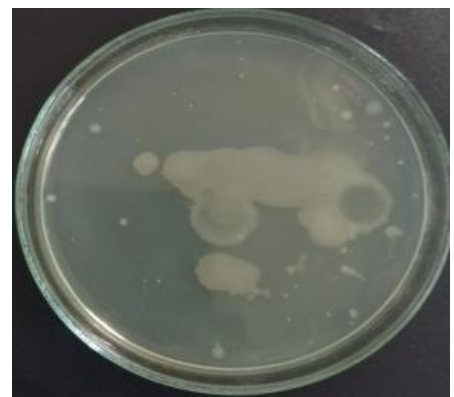

Gambar 2. Media TBX dengan Pertumbuhan Bakteri

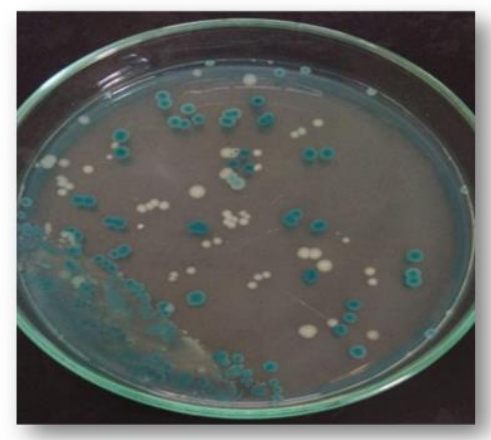

Gambar 3. Media TBX dengan Pertumbuhan Bakteri Escherichia Coli.

Bakteri Escherichia coli dapat mengakibatkan keracunan makanan serius pada manusia, antara lain diare berdarah karena eksotoksin yang dihasilkan bernama verotoksin. Sumber bakteri ini contohnya adalah daging yang belum masak, seperti daging hamburger yang belum matang. Pengujian angka lempeng total menunjukkan terdapat mikroba pada sampel air hujan yang disebabkan oleh adanya sumber kontaminasi di antaranya berasal dari atap dan bak penampung (Wiratna and Linda 2019).

\section{Perhitungan Angka Lempeng Total}

Perhitungan jumlah koloni bakteri yang tumbuh dilakukan pada koloni bakteri dengan ciri warna koloni spesifik hijau kebiruan menggunakan colony counter (Ahmad 2018b). Jumlah bakteri dinyatakan dalam satuan cfu/ml (colony-forming unit/ml) (Sutiknowati 2018).

Hasil pengujian dikatakan masuk dalam kriteria dapat ditinjau berdasarkan SNI No: 7388-2009 tentang batas maksimum cemaran mikroba. Batasan-batasan tersebut meliputi: total plate count maksimal 1 $\mathrm{x} 10^{6} \mathrm{CFU} / \mathrm{mL}$ total cemaran Escherichia coli tidak boleh melebihi angka 1 x $10^{1} \mathrm{CFU} / \mathrm{mL}$ (Adhianto 2015). Berikut data hasil pengujian disajikan pada Tabel 2 . 
Tabel 2. Hasil Pengujian ALT Bakteri Escherichia coli pada Media TBX

\begin{tabular}{|c|c|c|c|}
\hline Nama & $\begin{array}{l}\text { Produksi/ Hari } \\
\text { (ekor) }\end{array}$ & $\operatorname{ALT}(\mathrm{CFU} / \mathrm{ml}) 10^{1}$ & Keterangan \\
\hline 1. Tidar krajan $\mathrm{A}$ & 100 & 3 & + \\
\hline 2. Tidar krajan B & 50 & $>300$ & + \\
\hline 3. Tidar krajan $\mathrm{C}$ & 60 & 21 & + \\
\hline 4. Tidar krajan D & 300 & $>300$ & + \\
\hline 5. Tidar krajan E & 50 & $>300$ & + \\
\hline 6. Tidar krajan F & 200 & 31 & + \\
\hline 7. Tidar dudan A & 75 & $>300$ & + \\
\hline 8. Tidar dudan B & 40 & $>300$ & + \\
\hline 9. Tidar dudan $\mathrm{C}$ & 30 & 1 & + \\
\hline 10. Kp. Tulung & 33 & $>300$ & + \\
\hline 11. Menowo & 50 & 0 & - \\
\hline 12. Salakan & 20 & 1 & + \\
\hline 13. Tidar Warung A & 70 & 0 & - \\
\hline 14. Tidar Warung B & 50 & $>300$ & + \\
\hline 15. Potrobangsan & 10 & 1 & + \\
\hline 16. Nambangan A & 20 & 1 & + \\
\hline 17. Nambangan B & 15 & 6 & + \\
\hline 18. Paten Jurang & 20 & 0 & - \\
\hline
\end{tabular}

Berdasarkan data pengujian diatas, pengkategorian tingkat cemaran berdasarkanbatas maksimum cemaran mikroba. Sebanyak 11 dari 18 sampel uji dinyatakan sebagai sampel dengan kategori pencemaran tinggi. Data sampel yang diambil pada lokasi Rumah Potong Ayam dengan aktifitas produksi sedikit dan banyak tidak mempengaruhi pencemaran pada air bilasan tersebut, angka cemaran bakteri Escherichia coli, yaitu 1 x $10^{1} \mathrm{CFU} / \mathrm{ml}$. Aktifitas produksi pada lokasi usaha rumah pemotongan hewan menjadi salah satu faktor terjadinya pencemaran air sekitar.

\section{KESIMPULAN}

Terdapat $61,1 \%$ sampel dari air bilasan daging ayam dari total 18 tempat pemotongan ayam di Kota
Magelang tercemar dengan angka cemaran melebihi dari ambang batas.

Perlu adanya langkah-langkah berikutnya, yaitu pengolahan air limbah RPA dengan proses biofilter. Serta dapat disosialisasikan terkait cara mengolah daging menjadi makanan lauk pauk dengan benar sebagai upaya untuk mengurangi cemaran bakteri Escherichia coli pada lingkungan dan daging ayam.

\section{UCAPAN TERIMAKASIH}

Penulis mengucapkan terimakasih kepada Badan Penelitian dan Pengembangan (BALITBANG) KOTA MAGELANG atas dukungan dana atas penelitian tersebut. Penulis juga mengucapkan terimakasih kepada semua pihak yang telah membantu sehingga penelitian ini dapat terlaksana. 


\section{DAFTAR PUSTAKA}

Adhianto, K. (2015). Kandungan Mikroba pada Daging Sapi dari beberapa Pasar Tradisional di Bandar Lampung. 3(2):27-30.

Ahmad, M. (2018). Pemeriksaan Angka Lempeng Total Bakteri pada Minuman Sari Kedelai yang Diperjualbelikan di Kecamatan Manggala Kota Makassar. Jurnal Media Analis Kesehatan 1(1).

Anon. n.d. Anonim, (2014), Profil Kesehatan Kota Magelang Tahun 2014.

Arifudin, S., Khotimah, S., Mulyadi, A. 2013. Analisis Sebaran Bakteri Coliform Di Kanal A Kuala Dua Kabupaten Kubu Raya. 3:7.

Barcella, L., Barbaro, A.P., Rogolino, S.B. (2016). Colonial Morphology of Escherichia Coli: Impact of Detection in Clinical Specimens. Microbiologia Medica 31(2):51-55.

Halim, F., Warouw, S.M, Rampengan, N.H., Salendu, P. (2017). Hubungan Jumlah Koloni Escherichia Coli dengan Derajat Dehidrasi pada Diare Akut. Sari Pediatri 19(2):81-85.

Imamudin, M. 2001. Peranan Air Dalam Perspektif Al-Quran (Air Sebagai Sumber Kehidupan)." el-Hayah 3(1):41-45.

Pakpahan, R.S., Picauly, I., Mahayasa, I.N.W. (2015). Cemaran Mikroba Escherichia coli dan Total Bakteri Koliform pada Air Minum Isi Ulang. Kesmas: National Public Health Journal 9(4):300-307.

Sasongko, H. (2014). Uji Resistensi Bakteri Escherichia Coli dari Sungai Boyong Kabupaten Sleman terhadap Antibiotik Amoksisilin, Kloramfenikol, Sulfametoxasol, dan Streptomisin. Jurnal Bioedukatika. 2(1):25.

Sutiknowati, L.I. (2018). Keragaman Bakteri pada Perairan Sabang, Provinsi Aceh. 35(2):9.

Syarifuddin, A., Kamal, S., Yuliastuti, F., Pradani, M.P.K., Septianingrum, N.M.A.N. (2019). Ekstraksi Dan Identifikasi Metabolit Sekunder Dari Isolat Al6 Serta Potensinya Sebagai Antibakteri Terhadap Escherichia Coli. Jurnal Bioteknol Biosains Indones. 6(2):210.

Syarifuddin, A., Nanik, S., \& Kintoko. (2018). Profil Klt-Bioautografi dan Densitometri Fraksi Teraktif(Isolatkp13) dari Bakteri Rizosfer Kayu Putih 
A.Syarifuddin; F. Yuliastuti, M.P.K Pradani/Jurnal Kesehatan 13 (1) 2020, 46-53

(Melaleucaleucadendron L.). Jurnal Farmasi Sains dan Praktis 5(1):2733.

Syarifuddin, A., Sulistyani, N., Kintoko, K. (2018). Activity of Antibiotic Bacterial Isolate Kp13 and Cell Leakage Analysis of Escherichia coli Bacteria. jifi. 16(2):137.

Wiratna, G., Linda, R. (2019). Angka Lempeng Total Mikroba pada Minuman Teh di Kota Pontianak. 8:5.. 